\title{
Gluconeogenesis Induction
}

National Cancer Institute

\section{Source}

National Cancer Institute. Gluconeogenesis Induction. NCI Thesaurus. Code C40632.

Gluconeogenesis Induction involves initiation of the biosynthesis of glucose from 3carbon non-carbohydrate precursors, including amino acids (from protein breakdown during starvation). 